\title{
Pelaksanaan Layanan Bimbingan Konseling Karir dalam Meningkatkan Minat Siswa dalam Melanjutkan Studi Kelas XII di SMA Yadika Natar
}

\author{
Defriyanto, Neti Purnamasari
}

Dosen Fakultas Tarbiyah dan Keguruan, IAIN Raden Intan Lampung

Diterima: 2 Mei 2016. Disetujui: 5 Juli 2016. Dipublikasikan: Nopember 2016

\begin{abstract}
Abstrak: Kematangan karir peserta didik yang sangat rendah menjadi persoalan dalam dunia pendidikan terlihat dari peserta didik yang masih ragu terhadap karir masa depan dalam menentukan masa depan yang sesuai dengan dirinya. permasalahan dalam penelitian ini adalah "apakah upaya bimbingan karir dalam meningkatkan kematangan Karir Peserta Didik Kelas X Madrasah Aliyah Qudsiyah Kotabumi dapat ditingkatkan setelah melakukan konseling kelompok". Tujuan penelitian ini adalah untuk mengetahui kematangan karir dapat ditingkatkan dengan menggunakan layanan konseling kelompopada Peserta Didik Kelas X Madrasah Aliyah Kotabumi. Jenis peneltian adalah penelitian kuantitatif dengan metode menggunakan Design One Group Pretest - Posttest. sampel yang digunakan penelitian ini adalah sebanyak 10 peserta didik dari kelas X Madrsah Aliyah Qudsiyah Kotabumi Lmpung Utara hasil dari skor tertinggi penyebaran angket kematangan karir sebanyak 25 item. Angket yang digunakan sebagai Pretest Dan Posttest. Hasil rata-rata skor Kematangan Karir sebelum mengikuti adalah 47,2 dan setelah mengikuti konseling meningkat menjadi 73,3. dari hasil uji $\mathrm{t}$ dengan $(\mathrm{df})=9$ taraf signifikan 0,05 sebesar 2,262. Karena nilai thitung $\geq \mathrm{t}$ tabel $(4,063 \geq 2,262)$, maka Ho di tolak dan Ha diterima yang berarti ada pengaruh layanan informasi karir dalam maningkatkan kematangan karir efektif untuk meningkatkan kematangan karir pada peserta didik di madrasah aliyah qudsiyah Kotabumi lampung utara. saran yang di ajukan peneliti yaitu kepada guru bimbingan dan konseling agar dapat melaksanakan pelayanan bimbingan dan konseling dengan menyertakan layanan informasi pada peserta didik.
\end{abstract}

Kata kunci: Layanan Informasi Karir Dalam Meningkatkan Kematangan Karir

\section{Pendahuluan}

Dalam belajar diperlukan suatu pemusatan perhatian agar apa yang dipelajari dapat dipahami. Sehingga siswa dapat melakukan sesuatu yang sebelumnya tidak dapat dilakukan. Terjadilah suatu perubahan kelakuan.Perubahan kelakuan ini meliputi seluruh pribadi siswa baik kognitip, psikomotor maupun afektif. W.S Winkel mengatakan bahwa minat adalah kecendrungan yang agak menetap untuk merasa tertarik pada bidang-bidang tertentu dan merasa senang berkecimpung dalam bidang itu. Sedangkan menurut Witherington minat adalah kesadaran seseorang terhadap suatu objek, seseorang, suatu hal atau situasi tertentu yang memandang sangkut paut dengan dirinya atau dipandang sebagai sesuatu yang sadar.

Minat adalah salah satu faktor yang turut menentukan atau mempengaruhi keinginan seseorang dalam melakukan atau menentukan sesuatu hal yang ingin dia lakukan. Menurut Djamarah minat adalah rasa lebih suka dan rasa ketertarikan pada suatu hal atau aktifitas tanpa ada yang menyuruh.

Pendapat tersebut bisa dipahami bahwa minat merupakan ketertarikan atau keinginan individu yang timbul dan bisa mengarahkan individu kepada pilihan, baik terhadap orang, benda, situasi maupun terhadap suatu kegiatan tanpa adanya paksaan atau pamrih. Adanya minat dalam diri individu akan menyebabkan individu tersebut berhubungan secara aktif dengan objek yang diamatinya.Pada kenyataannya, masih banyak siswa sekolah menengah atas yang masih rendah minat melanjutkan studinya, bahkan ada yang tidak berminat sama sekali. Berkaitan dengan minat studi lanjut tersebut ada sebagian siswa yang sangat berminat, ada yang biasa - biasa saja, ada yang kurang atau bahkan tidak berminat. Rendahnya minat melanjutkan studi, khususnya ke perguruan tinggi justru akan berdampak nantinya pada pemilihan jurusan atau pekerjaan apa yang cocok atau sesuai dengan minat dan bakatnya. Di samping itu, apabila siswa menganggur setelah lulus SMA,justru akan menambah angka 
pengangguran di tingkat sekolah menengah atas. Lain halnya jika siswa menempuh pendidikan tinggi atau melanjutkan studi ke perguruan tinggi.

Mereka akan lebih luas pemahamannya dan tentunya memiliki bekal untuk memasuki dunia kerja, dikarenakan jurusan yang dipilih tersebut sesuai dengan bakat dan minatnya. Dalam hal ini perlukan seorang pembimbing yang bisa membantu siswa dalam meningkatkan minatnya dalam melanjutkan studinya. Hal ini sangat membantu siswa karena dengan siswa melantujkan studi nya ke jenjang yang lebih tinggi maka hal itu akan membantu siswa dalam menempuh karier nya untuk kedepan supaya lebih suskes dan mengurangi pengangguran didunia kerja. Karena yang kita ketahui dizaman sekarang ini persaingan dunia kerja semakin sulit.

Maka dari itu peneliti ingin mencoba meneleti bagaimana pelaksanaan layanan Bimbingan konseling Karier dalam meningkatkan minat siswa dalam melanjutkan studinya yang diharapkan bisa membantu siswa dalam menumbuhkan minat nya untuk melanjutkan studinya dan membantu siswa menemukan jalan yang harus ditempuhnya setelah lulus sekolah.

Menurut Sukardi mendefinisikan bimbingan karir adalah layanan bantuan yang diberikan kepada individu- individu untuk memilih, menyiapkan, menyesuaikan, dan menetapkan dirinya dalam pendidikan maupun pekerjaan yang sesuai serta memperoleh kebahagiaan dari padanya Sedangkan menurut Sukardi bimbingan karier adalah suatu perangkat, lebih tepat nya suatu program sistematis, proses, layanan atau lebih tepat nya suatu layanan yang dimaksudkan untuk membantu individu memahami dan berbuat atas dasar pengenalan diri dan pengenalan kesempatan-kesempatan dalam pekerjaan, pendidikan, waktu luang serta mengembangkan ketrampilan- ketrampilan mengambil keputusan sehingga yang bersangkutan dapat menciptakan dan mengelola perkembangan karernya. Berkaitan dengan sekolah, bimbingan karir dapat di pandang sebagai suatu proses perkembangan yang berkesinambungan yang membantu terutama dalam hal perencanaan karir, pembuatan keputusan, perkembangan ketrampilan/ keahlian, informasi karir, dan pemahaman diri.

Dari pendapat tersebut dapat diambil kesimpulan bahwa, bimbingan karir adalah suatu proses bantuan, layanan informasi, dan pendekatan terhadap pengambilan keputusan karir dan mengakui bahwa keputusan tersebut adalah yang paling tepat/ sesuai dengan keadaan dirinya dihubungkan dengan persyaratan- persyaratan karir atau studi lanjut yang akan ditekuninya.

Kelebihan layanan bimbingan karir dari pada layanan lain berkaitan dengan minat studi lanjut adalah antara lain, dapat membantu siswa mempersiapkan pengambilan keputusan, dapat membantu siswa mengembangkan beberapa kepercayaan dalam diri sendiri, dapat membantu siswa menemukan beberapa makna dari aktivitas siswa di sekolah, dapat memberikan ketenangan bagi diri siswa untuk mengenal kesempatan-kesempatan yang baik yang ditemukannya di sekolah maupun di luar sekolah, dapat membantu siswa menentukan apa yang seharusnya dilakukan sekarang dalam kaitannya dengan apa yang diinginkan selanjutnya.

Peneliti berharap setelah dilakukan layanan bimbingan karir dalam meningkatkan minat melanjutkan studi, siswa memiliki kecenderungan keinginan atau minatnya untuk melanjutkan studi. Berdasarkan data yang didapat dari hasil wawancara kepada guru bimbingan konseling SMA YADIKA NATAR, bahwasanya siswa yang mengalami minat rendah dikarenakan atau disebabkan oleh dua faktor yaitu faktor internal dan faktor eksternal.

Faktor internal tersebut meliputi a). kurang motivasi dari dalam diri siswa sehingga tidak ada nya keingginan atau minat untuk melanjutkan studi.b) kemampuan siswa yang kurang, baik secara materi dan non materi. Sedangkan faktor eskternal yaitu meliputi: a)latar belakang orang tua siswa yang termasuk kategori menengah kebawah, b) faktor ekonomi keluarga yang menyebabkan siswa untuk bekerja setelah lulus SMA.

Berdasarkan uraian latar belakang di atas penulis bermaksud mengadakan penelitian tentang pelaksanaan layanan bimbingan karir terhadap minat melanjutkan studi, hal inilah yang menjadi fokus dalam penelitian ini. Menurut John Holland (1973), individu tertarik pada suatu 
karir tertentu karena kepribadiannya dan berbagai variabel yang melatarbelakanginya. Pada dasarnya, pilihan karir merupakan ekspresi atau perluasan kepribadian ke dalam dunia kerja yang diikuti dengan pengidentifikasian terhadap stereotipe okupasional tertentu. Perbandingan antara self dengan persepsi tentang suatu okupasi dan penerimaan atau penolakannya merupakan faktor penentu utama dalam pilihan karir. Harmoni antara pandangan seseorang terhadap dirinya dengan okupasi yang disukainya membentuk "modal personal style".

Orientasi kesenangan pribadi (modal personal orientation) merupakan proses perkembangan yang terbentuk melalui hereditas dan pengalaman hidup individu dalam bereaksi terhadap tuntutan lingkungannya. Sentral bagi teori Holland adalah konsep bahwa individu memilih sebuah karir untuk memuaskan orientasi kesenangan pribadinya. Jika individu telah mengembangkan suatu orientasi yang dominant, maka akan lebih besar kemungkinan baginya mendapatkan kepuasan dalam lingkungan okupasi yang sesuai. Akan tetapi, jika dia belum dapat menentukan pilihan, maka kemungkinan mendapat kepuasan itu akan hilang. Orientasi kesenangan pribadi yang didukung oleh lingkungan kerja yang sesuai akan menentukan pilihan.

Gaya hidup individu Dalam proses pembuatan keputusan karir, Holland berasumsi bahwa tingkat pencapaian dalam sebuah karir ditentukan terutama oleh individual self-evaluations. Intelegensi dipandang sebagai kurang penting dibanding kepribadian dan minat. Lebih jauh, faktor inteligensi sudah tercakup di dalam klasifikasi tipe-tipe kepribadian; misalnya, individu yang investigatif pada umumnya cerdas dan secara alami memiliki keterampilan penalaran analitik dan abstrak. Menurut Holland, stabilitas pilihan karir sangat tergantung pada dominansi orientasi personal individu, yang dipengaruhi oleh lingkungannya.

Teori Holland memberikan penekanan pada ketepatan self-knowledge dan informasi karir yang diperlukan untuk pembuatan keputusan karir. Dampaknya sangat besar pada prosedur asesmen minat dan prosedur konseling karir. Implikasinya untuk konseling adalah bahwa tujuan utama konseling adalah mengembangkan strategi untuk meningkatkan pengetahuan tentang diri, berbagai persyaratan okupasional dan berbagai macam lingkungan kerja.

Dalam bidang bimbingan dankonseling, kita pasti menjumpai bimbingan karier. Dan dibawah ini akan ada penjelasan mengenai apa itu bimbingankarier. Pengertian bimbingan karir menurut para ahli adalah sebagai berikut:

a. Menurut Winkel Bimbingan konseling karir adalah bimbingan dalam mempersiapkan diri menghadapi dunia kerja, dalam memilih lapangan kerja atau jabatan/profesi tertentu serta membekali diri supaya siap memangku jabatan itu, dan dalam menyesuaikan diri dengan berbagai tuntutan dari lapanan pekerjaan yang dimasuki. Bimbingan karir juga dapat dipakai sebagai sarana pemenuhan kebutuhan perkembangan peserta didik yang harus dilihat sebagai bagaian integral dari program pendidikan yang diintegrasikan dalam setiap pengalaman belajar bidang studi.

b. Menurut Marsudi Bimbingan konseling karir adalah suatu perangkat, lebih tepatnya suatu program yang sistematik, proses, teknik, atau layanan yang dimaksudkan untuk membantu individu memahami dan berbuat atas dasar pengenalan diri dan pengenalan kesempatankesempatan dalam pekerjaan, pendidikan, dan waktu luang, serta mengembangkan ketrampilan-ketrampilan mengambil keputusan sehingga yang bersangkutan dapat menciptakan dan mengelola perkembangan karirnya.

c. Menurut National Vocational Guidance Association (NVGA), Bimbingan konseling karier diartikan sebagai proses membantu dalam memilih pekerjaan, mempersiapkan, memasuki dan memperoleh kemajuan di dalamnya.

d. Menurut Rochman Natawidjaja Bimbingan konseling karir adalah suatu proses membantu seseorang untuk mengerti dan menerima gambaran tentang diri pribadinya dan gambaran tentang dunia kerja di luar dirinya, mempertemukan gambaran diri tersebut dengan dunia 
kerja itu untuk pada akhirnya dapat memilih bidang pekejaan, memasukinya dan membina karir dalam bidang tersebut.

e. Menurut Mohamad Surya Bimbingan konseling karir merupakan salah satu jenis bimbingan yang berusaha membantu individu dalam memecahkan masalah karir, untuk memperoleh penyesuaian diri yang sebaik-baiknya antara kemampuan dengan lingkungan hidupnya, memperoleh keberhasilan dan perwujudan diri dalam perjalanan hidupnya.

f. Manrihubimbingan konseling karir adalah suatu perangkat, lebih tepatnya suatu program yang sistematik, proses- proses, teknik-teknik, atau layanan- layanan yang dimaksudkan untuk membantu individu memahami dan berbuat atas dasar pengenalan diri dan pengenalan kesempatan-kesempatan dalam pekerjaan, pendidikan dan waktu luang, serta mengembangkan ketrampilan-ketrampilan mengambil keputusan sehingga yang bersangkutan dapat menciptakan dan mengelola perkembangan karirnya.

g. Menurut Sukardi mendefinisikan bimbingan konseling karir adalah layanan bantuan yang diberikan kepada individu-individu untuk memilih, menyiapkan, menyesuaikan, dan menetapkan dirinya dalam pekerjaan yang sesuai serta memperoleh kebahagiaan daripadanya. Berkaitan dengan sekolah, bimbingan karir dapat dipandang sebagai suatu proses perkembangan yang berkesinambungan yang membantu terutama dalam hal perencanaan karir, pembuatan keputusan, perkembangan ketrampilan/ keahlian informasi karir, dan pemahaman diri.

Berdasarkan beberapa pendapat para ahli di atas dapat dijelaskan bahwa bimbingan konseling karir merupakan suatu aktivitas berupa bimbingan yang dilakukan oleh konselor terhadap konseli dengan tujuan membantu memecahkan masalah karier siswa serta memfasilitasi perkembangan karir siswa melalui pendidikan karir/jabatan baik sekarang maupun masa yang akan dating. Bimbingan karir bukan hanya memberikan bimbingan jabatan, tetapi mempunyai arti yang lebih luas, yaitu suatu proses bantuan, layanan, pendekatan terhadap individu agar dapat mengenal dan memahami dirinya, mengenal dunia kerja, merencanakan masa depan yang sesuai dengan bentuk kehidupan yang diharapkannya, mampu menentukan dan mengambil keputusan secara tepat dan bertanggung jawab atas keputusan yang diambilnya itu sehingga mampu mewujudkan dirinya secara bermakna.

Suatu kegiatan akan berjalan dengan baik dan lancar apabila ada minat yang timbul karena adanya kebutuhan. Dengan adanya kebutuhan, maka timbulah motivasi yang disebabkan adanya minat yang besar terhadap sesuatu yang mengandung arti, bernilai tinggi bagi orang itu atau karena ia akan memenuhi dirinya dengan terpenuhinya kebutuhan ia akan merasa senang.

Minat berarti kecendrungan dalam diri individu untuk tertarik pada suatu obyek atau menyenangkan suatu obyek. Minat adalah kecendrungan yang tetap untuk memperhatikan dan mengenal beberapa kegiatan. Pengertian minat menurut beberapa ahli yaitu:

1) Menurut Bingham dan Mac Daniel, minatadalah kecenderungan orang untuk tertarik dalam suatupengalaman dan untuk terus demikian itu. Kecenderungan itu tetapbertahan sekalipun seseorang sibuk mengerjakan hal lain. Kegiatanyang diikuti seseorang karena kegiatan itu menarik baginya,merupakan perwujudan minatnya.

2) Agus sujanta menjelaskan bahwa minat adalah suatu pemusatan perhatian yang tidak disengaja yang terlahir dengan penuh kemauannya dan yang tergantung dari bakat dan lingkungannya.

3) Ahmad D. Marimba menyatakan bahwa minat adalah kecendrungan jiwa kearah sesuatu karena sesuatu itu mengandung arti bagi kita, sesuatu itu memenuhi kebutuhan dan dapat menyenangkan kita, jadi minat bukanlah kecendrungan yang dipaksa. Berdasarkan pendapat diatas dapat penulis perjelas bahwa minat keinginan melakukan sesuatu yang menurutnya ada manfaat bagi dirinya, menyenangkan dan dapat memenuhi segala kebutuhannya. 
4) Abdul Rahman Saleh menyatakan bahwa minat adalah sumber hasrat belajar , minat itu erat hubungannya dengan kepribadian seseorang, ketiga fungsi jiwa kognitif, emosi dan konasi terdapat dalam minat kadang-kadang minat itu timbul dengan sendirinya dan kadang- kadang diusahakan.

5) W.S Winkel menyatakan bahwa minat adalah kecendrungan yang agak menetap dalam subyek untuk merasa tertarik pada bidang-bidang tertentu dan merasa senang berkecimbung dalam bidang-bidang tertentu.

6) Djaali menyatakan bahwa minat adalah rasa lebih suka dan rasa ketertarikan pada suatu hal atau aktivitas, tanpa ada yang menyuruh. Minat dapat diekpresikan melalui penyataan yang menunjukan bahwa seseorang lebih menyukai hal dari pada hal lainnya.

7) Andi Mappiare juga berpendapat bahwa minatadalah suatu perangkat mental yangterdiri suatu campuran dariperasaan, harapan, pendirian, prasangka, rasa takut, ataukecenderungan lain yangmengarahkan individu kepada suatu pilihantertentu.

8) Sedangkan menurut Abd. RahmanAbr minat mengandung unsur kognisi (logika), emosi(perasaan), dan konasi (kehendak). Unsur konasi dalam arti minat inididahului oleh pengetahuan dan informasi mengenai objek yangdituju adalah minat tersebut. Unsur emosi terdapat karena dalampartisipasi atau pengalaman tertentu (rasa senang), sedangkan unsurekonasi merupakan kelanjutan dari kedua unsur tersebut yangdiwujudkan dalam bentuk kemampuan dan hasrat untukmelakukan sesuatu kegiatan.

9) Menurut Slameto minat juga dapat diartikansebagai suatu rasa lebih suka dan rasa keterkaitan pada suatu halaktivitas, tanpa ada yang menyuruh. Minat pada dasarnya adalahpenerimaan akan sesuatu hubungan antara dir sendiri dengan sesuatudi luar diri. Semakin kuat atau dekat hubungan tersebut, semakinbesar pula minat. Minat dapat diekspresikan melalui suatupernyataan yang menunjukkan bahwa siswa lebih menyukai suatuhal daripada hal lainnya, dapat pula ditunjukkan melalui partisipasidalam suatu aktivitas.

10) Menurut Whitherington, minat adalah kesadaranseseorang, bahwa suatu objek, seseorang, suatu soal atau suatusituasi mengandung sangkut paut dengan dirinya.

11) Menurut Muhibbinminat (interest) adalah kecenderungan dan kegairahan yang tinggi atau keinginan yang besar terhadap sesuatu. Menurut Djamarah bahwa minat adalah kecenderungan yang mantap untuk memperhatikan dan mengenang beberapa aktifitas.

Minata dalah suatu rasa lebih suka dan rasa ketertarikan pada suatu hal atau aktivitas, tanpa ada yang menyuruh. Minat pada dasarnya penerimaan akan suatu hubungan antara diri sendiri dengan sesuatu diluar diri. Semain kuat atau dekat hubungan tersebut, maka akan semakin besar minat. Minat dapat timbul karena daya tarik dari luar dan juga datang dari hati sanubari. Menurut Kamus Umum Bahasa Indonesia, melanjutkan memiliki arti meneruskan, menyambung, mempertinggi. Sedangkan studi memiliki arti kajian, telaah, penelitian yang bersifat ilmiah.

Berdasarkan definisi tersebut, maka dapat ditarik kesimpulan bahwa minat melanjutkan studi merupakan pernyataan psikis yang menunjukkan seseorang untuk memusatkan perhatian pada suatu objek atau aktivitas untuk mengembangkan dirinya menuju kelanjutan studi setelah lulus sekolah.

Mengembangkan minat dalam melanjutkan studi pada dasarnya adalah membantu siswa melihat bagaimana hubungan antara materi yang diharapkan untuk dipelajarinya dengan dirinya sendiri sebagai individu. Proses ini berarti menunjukkan pada siswa bagaiman pengetahuan atau kecakapan tertentu mempengaruhi dirinya, melalui tujuan- tujuannya, memuaskan kebutuhan- kebutuhannya.

Dari beberapa pendapat di atas, dapat disimpulkan bahwaminat adalah suatu perasaan suka atau tertarik terhadap suatu objekdiluar diri individu yang diikuti dengan munculnya perhatianterhadap objek tersebut yang mengakibatkan seseorang mempunyaikeinginan untuk 
terlibat atau berkecimpung dalam suatu objektersebut, karena dirasakan bermakna pada dirinya sehingga adaharapan dari objek yang dituju.

Minat yang terjadi dalam diri individu dipengaruhi dua faktoryang menentukan yaitu faktor keinginan dari dalam diri individuatau keinginan dari luar diri individu. Minat dari dalam individuberupa keinginan atausenang pada perbuatan. Orang tersebut senangmelakukan perbuatan itu demi perbuatan itu sendiri. Minat dari luarindividu berupa dorongan atau paksaan dari luar individu untukmelakukan sesuatu perbuatan. Menurut Siti Rahayu Hadinoto, ada dua faktoryang mempengaruhi minat seseorang, yaitu:

a) Faktor dari dalam (intrinsik) yaitu berarti bahwa sesuatuperbuatan memang diinginkan karena seseorang senangmelakukannya. Di sini minat datang dari diri orang itu sendiri.Orang tersebut senang melakukanperbuatan itu demiperbuatan itu sendiri.

b) Faktor dari luar (ekstrinsik) yaitu berarti bahwa sesuatuperbuatan dilakukan atas dasar dorongan atau pelaksanaan dariluar. Orang melakukan kegiatan ini karena ia didorong ataudipaksa dari luar.

\section{Metode Penelitian}

Penelitian kualitatif adalah suatu proses penyelidikan untuk memahami masalah social berdasarkan pada penciptaan gambaran holistik lengkap yang dibentuk dengan kata-kata, melaporkan pandangan informan secara terperinci dan disusun dalam sebuah latar alamiah. Dari pendapat diatas, maka dapat diketahui bahwa penelitian kualitatif merupakan penelitian yang digunakan apabila faktor penelitian tidak dapat dikuantifikasikan atau dihitung sehingga variable tidak dapat diungkapkan dengan angka seperti, persepsi, pendapat, anggapan dan sebagainya. Menurut teori penlitian kualitatif, agar penelitiannya dapat benar- benar berkualitas maka data yang dikumpulkan harus lengkap, yaitu data primer dan data skunder.

Dalam penelitian ini penulis menggunakan metode penelitian kualitatif, yaitu dengan digambarkan dengan kata-kata atau kalimat dipisah-pisah menurut kategori untuk memperoleh kesimpulan. Jenis penelitian yang dipakai adalah penelitian deskriptif Kualitatif. Penelitian yang dilakukan untuk mengetahui nilai variabel mandiri, baik satu variabel atau lebih tanpa membuat perbandingan atau menghubungkan antara variabel satu dengan yang lain. Dalam hal ini penulis menafsirkan melalui metode observasi, wawancara, dokumentasi, sampai pada analisis data sehingga persoalan menjadi jelas dan dapat digambarkan dengan jelas. Penelitian kualitatif pada umumnya dirancang untuk memberikan pengalaman senyatanya dan menangkap makna sebagai mana yang tercipta di lapangan penelitian melalui antraksi langsung antara peneliti dan yang akan diteliti.

\section{Hasil dan Pembahasan}

Pada bab IV ini penulis akan mendeskripsikan hasil penelitian mengenai pelaksanaan layanan bimbingan dan konseling karir dalam meningkatkan minat siswa melanjutkan studi kelas XII sma yadika natar lampung selatan tahun ajaran 2015/2016. Data yang akan diolah dan dianalisis dalam penelitian ini adalah data mengenaipelaksanaan layanan bimbingan dan konseling karir dalam meningkatkan minat siswa yang akan diperoleh melalui alat pengumpulan data yaitu interview terhadap guru bimbingan dan konseling di SMA YADIKA Natar Lampung Selatan. Data tersebut dianalisis dengan menggunakan analisis induktif, yaitu suatu analisis berdasarkan data yang diperoleh, selanjutnya dikembangkan dengan pola hubungan pola tertentu atau menjadi hipotesis. Untuk memperoleh data yang diperlukan tersebut penulis menggunakan beberapa metode yang telah ditetapkan pada bab sebelumnya yaitu metode obserasi, metode wawancara dan dokumentasi. 
Metodeobservasi dilakukan dengan cara melihat dan mengamati pelaksanaan layanan bimbingan dan konseling dalam meningkatkan minat siswa kelas XII SMA YADIKA Natar Lampung Selatan, serta mengamati sarana dan prasarana yang menunjang berjalannya pelaksanaan layanan. Metode wawancara dilakukan kepada guru BK untuk membicarakan atau untuk mendapatkan informasi mengenai pelaksaan layanan bimbingan dan konseling karir dalam meningkatkan minat siswa melanjutkan studi kelas XII SMA YADIKA Natar Lampung Selatan. Selain menggunakan metode observasi dan wawacara, peneliti juga menggunakan metode dokumentasi. Metode ini peneliti gunakan untuk memperoleh data- data yang diperlukan untuk melengkapi dan memperkuat data yang telah ada. Berdasarkan hasil dari wawancara dan observasi dapat diketahui bahwa pelaksanaan layanan bimbingan dan konseling karir dalam meningkatkan minat siswa melanjutkan studi kelas XII SMA YADIKA NATAR yaitu:

1. Identifikasi Peserta Didik

Langkah awal yang dilakukan oleh guru BK dalam meningkatkan minat pada peserta didik adalah dengan cara melakukan identifikasi peserta didik. Pengidentifikasian peserta didik ini dilakukan oleh guru BK dengan cara pengamatan (observasi) dan wawancara pada peserta didik. Dengancara ini guru BK dapat megetahui dan memastikan minat siswa dalam melanjutkan studinya.

Berdasarkan data hasil dari wawancara dengan guru bimbingan konseling maka dapat diketahui bahwa siswa mengalami rendahnya minat dalam melanjutkan studi, hal ini dikarenakan:

a. kurangnya rasa senang siswa untuk melanjutkan studi

b. b. kurangnya ketertarikan siswa untuk melanjutkan studi

c. sedikitnya perhatian siswa dalam melanjutkan studi.

d. d. Pemahaman siswa yang kurang tentang dirinya sehingga siswa tidak menyadari kemampuan yang ia miliki.

e. Kurangnya motivasi dalam diri siswa untuk melanjutkan studi.

f. Keterlibatan siswa yang kurang dalam pembelajaran

g. Faktor ekonomi keluarga yang kurang memadai sehingga siswa tidak bisa melanjutkan studi dan pengaruh lingkungan serta teman sebaya yang hampir mayoritas tidak melanjutkan studi lebih memilih untuk langsung bekerja.

Sesuai permasalahan yang timbul dapat dikatakan minatsiswa rendah sesuai dengan indikator, dengan adanya permasalahan yang ada selaku guru BK melakukan observasi dan wawancara dengan peserta didik bahwasannya peserta didik mengalami permasalahan dalam rendah nya minat melanjutkan studi sebagaimana pernyataan guru BK dibawah ini:

"Dari informasi yang saya dapat dari hasil observasi dan wawancara kepada peserta didik bahwasanya peserta didik mengalami masalah dalam minat untuk melanjutkan studi, banyak siswa yang mengalami masalah dalam minat. Kurangnya minat siswa dalam melanjutkan studi dikarenakan dua faktor yatu faktor dari dalam dan luar. Minat seseorang tumbuh karena adanya dorongan dari siswa itu sendiri dan dibutuhkan juga dorongan dari luar atau orang lain. Melihat masalah yang ada saya selaku guru BK melakukan identifikasi masalah, setelah saya mengetahui permasalahan yang ada saya akan memberikan layanan yaitu layanan BK Karir untuk meningkatkan minat, dikarenakan masalah yang dihadapi siswa sama maka layanan akan diberikan secara kelompok".

2. Treatment atau Pelaksanaan Layanan.

Setelah melakukan identifikasisiswa, langkah selanjutnya yang dilakukan oleh guru BK dalam meningkatkan minat siswa melanjutkan studiyaitu memberikan layanan bimbingan konseling karir yang dilaksanakan secara bimbingan kelompok. Guru bimbingan konseling memilih layanan bimbingan konseling karir dilaksanakan secara bimbingan kelompok dikarenakan siswa memiliki kesamaanya itu rendahnya minat siswa dalam melanjutkan studi. 
Pelaksanaan layanan bimbingan konseling karir yang dilaksanakan secara bimbingan kelompok oleh guru Bimbingan Konseling SMA YADIKA terdiridari 4 tahap, yaitu tahap pembentukan, tahap peralihan, tahap kegiataan atau pembahasan dan tahap pengakhiran. Secara lebih rinci proses pelaksanaan layanan bimbingan konseling karir yang dilaksanakan secara bimbingan kelompok adalah sebagai berikut:

Dalam tahap ini guru bimbingan konseling menjelaskan tentang pengertian bimbingan konseling karir, bimbingan kelompok serta menjelaskan tujuan, manfaat dan harapan yang ingin dicapai setelah melaksanakan kegiatan bimbingan kelompok ini. Selain menjelaskan hal yang tersebut diatas, guru bimbingankon seling juga menjelaskan tentang asas-asas yang digunakan dalam bimbingan kelomok, hal ini sangat penting dijelaskan agar siswa merasanyaman dan percaya sehingga siswa mengungkapkan semua masalah yang dihada pinya tanpa rasa ragu. Setelah menjelaskan, guru bimbingan konseling memberikan kesempatan kepada siswa untuk melakukan perkenalan, setiap anggota kelompok memperkenalkan dirinya masing-masing, setelah memperkenalkan diri guru bimbingan konseling menjelaskan tujuan diadakannya perkenalanya itu agar kebersamaan antara kelompok terbangun dan saling terbuka.

Selanjutnya guru bimbingan konseling mulai mengutarakan tentang tujuan dilaksanakannya bimbingan kelompok ini dan setiap anggota mulai mengungkapkan tujuan mereka masing-masing. Namun diperoleh satu kesamaan permasalahan yang dihadapi siswa yaitu permasalahan rendahnya minat siswa melanjutkan studi.

Setelah melakukan tahap pembentukan maka tahap selanjutnya yaitu tahap peralihan dimana pemimpin kelompok menjelaskan kepada anggota kelompok bahwasanya kegiatan yang berteman rendahnya minat melanjutkan studi ini dapat berja;an dengan lancar dan sesuai dengan apa yang diharapkan. Pada tahap peralihan ini pemimpin kelompok atau guru BK lebih memfokuskan pada permasalahan siswa yaitu rendahnya minat siswa melanjutkan studi. Sebagaimana yang dikatakan oleh guru BK: " anak-anak apakah kalian semua sudah siap dalam mengikuti kegiatan ini? Ibu berharap kalian dapat mengikuti kegiatan ini sampai akhir dan ibu berharap disaat ibu bertanya dan memberikan kesempatan kalian untuk berbicara atau beragumen ibu harap kalian dapat berbicara dengan sejujur- jujurnya tanpa adanya rasa malu, karena harapan kita semua dengan adanya kegiatan ini masalah yang dihadapi tentang rendahnya minat belajar bisa teratasi”. Berdasarkan pemaparan pemimpin kelompok diatas, sudah jelas bahwa anggota kelompok sudah siap dalam mengikuti kegiatan ini sampai akhir dan siap dalam melanjutkan ke tahap selanjutnya.

Pada tahap kegiatan ini pemimpin kelompok atau guru BK menjelaskan atau mengemukakan satu topik atau pembahasan yaitu tentang "rendahnya minat melanjutkan studi". Pemimpin kelompok menjelaskan tentang pengertin minat, pentingnya studi untuk masa depan, sebab dan faktor- faktor yang menyebabkan rendahnya minat dalam melanjutkan studi.

Dalam kegiatan ini anggota kelompok diberikan kesempatan untuk bertanya tentang materi yang telah disampaikan oleh pemimpin kelompok. Pertanyaan dan respon anggota kelompok sangat antusias dan pemimpin kelompok memberikan jawaban atas pertanyaan yang diberikan oleh anggota kelompok. Jawaban dari pemimpin kelompok diberikan secara tegas, cepat dan pemimpin kelompok memberikan penegasan- penagasan atas pertanyaan anggota kelompok dan jawabannya sesuai dengan apa yang diharapkan oleh anggota kelompok. Seperti pertanyaan yang diberikan anggota kelompok kepada pemimpin kelompok, yaitu:

"Bu apa pentinya melanjutkan studi sedangkan banyak orang-orang yang lulusan SMA bisa bekerja dan menghasilkan uang"

Jawaban Pimpinan Kelompok" Melanjutkan studi sangat penting bagi masa depan bagi karir kita, dengan pendidikan yang tinggi wawasan kita pun akan bertambah, dengan 
pendidikan kita bisa membedakan mana yang benar dan mana yang salah. Semakin tinggi pendidikan semakin mudah seseorang untuk mencapai karir nya. Apa kalian tidak mau menjadi orang yang sukses? Semua anggota menjawab "Mau bu". Nah jika ingin sukses dan citacitanya tercapai jangan pernah lelah untuk belajar dan lanjutkan studi kalian kejenjang yang lebih tinggi”.

Pertanyaan anggota kelompok"Bu bagaimana caranya menumbuhkan minat melanjutkan studi”

Jawaban pemimpin kelompok " nah pertanyaan yang bagus sekali, minat adalah keinginan, untuk menumbuhkan minat kita harus mempunyai keinginan yang besar, contohnya keinginan untuk melanjutkan studi, keinginan untuk suskes, kita harus mempunyai pandangan kedepan. Untuk menumbuhkan minat kita harus memiliki motivasi yang tinggi."

Pada tahap kegiatan ini adanya kegiatan yang meliputi penguraian, diskusi, pelatihan pengembangan diri, pengetahuan dan ketrampilan. Adapun aktivitas tanya jawab yang dilakukan oleh guru bimbingan konseling atau pemimipin kelompok dengan anggota kelompok adalah sebagai berikut:

1. Menanyakan kepada anggota kelompok apa yang dimaskud dengan minat dan apa yang dimaksud dengan studi?

2. Meminta respon peserta didik tentang Apa pentingnya melanjutkan studi ke perguruan tinggi? Dan apa dampak nya bila tidak melanjutkan studi?

3. Meminta siswa mengemukakan bagaimana cara mereka dalam meningkatkan minat dari dalam dirinya untuk melanjutkan studi. Pada tahap kegiatan ini guru BK atau pemimpin kelompok sangat megaharapkan siswa berperan aktif dan dapat menumbuhkan minatnya dalam melanjtkan studi kejenjang perguruan tinggi dan tiada hentinya dalam menuntut ilmu.

Tahap terakhir ini merupakan tahap terakhir dalam kegiatan ini, pemimpin kelompok menyampaikan bahwa kegiatan ini akan segera berakhir dan ditutup. Pemimpin kelompok meminta salah satu dari anggota kelompok untuk menyampaikan kesimpulan dari kegiatan ini.

"melanjutkan studi ke jenjang yang lebih tinggi itu sangat penting untuk masa depan, tanpa studi kita tidak mengetahui apa-apa, dengan pendidikan yang tinggi kita bisa dengan mudah dalam menggapai cita-cita."

Pada tahap ini guru BK atau pemimpin kelompok memberikan pernyataan yang menyatakan terkait penawaran untuk melakukan pertemuan kembali dan memberikan selebaranya itula iseg, peserta didik menjawab sangat senang adanya layanan bimbingan kelompok dan mengharapkan diadakan kembali bimbingan kelompok. Dan guru BK menutu pkegiatan kelompok dengan mengucap salam.

Dari pemaparan diatas dapat disimpulkan bahwasannya upaya guru bimbingan dan konseling dalam meningkatkan minat siswa melanjutkan studi cukup meningkat meskipun tidak semua tetapi sudah banyak pesertadidik yang ingin melanjutkan studi kejenjang yang lebih tinggi. Pelaksanaan layanan dilakukan secara bimbingan kelompok, hal ini dilakukan karena siswa memiliki masalah yang sama yaitu kurangnya minat siswa dalam melanjutkan studi. Layanan ini dilakukakan dengan dua cara yaitu identifikasi masalah siswa dan pelaksanaan layanan bimbingan konseling karir secara bimbingan kelompok. Setelah dilaksanakannya layanan minat Para siswa meningkat, siswa lebih berantusias dan lebih giat lagi dalam belajar agar mereka bisa masuk keperguruan tinggi yang mereka inginkan.

Berdasarkan hasil analisis data dari observasi, wawancara dan dokumentasi yang diperoleh dari guru bimbingan konseling dilaksanakan sesuai dengan kebutuhan dan masalah yang dihadapi siswa yaitu rendahnya minat siswa dalam melanjutkan studi disekolah SMA YADIKA Natar. Dalam pelaksanaan ini diambil sampel kelas XII. 
Dalam proses pelaksanaan layanan bimbingan konseling karir yang dilakukan secara kelompok dapat terungkap beberapa faktor yang memyebabkan rendahnya minat siswa dalam melanjutkan studi. Seperti hasil wawancara yang dilakukan kepada peserta didik bahwasanya rendahnya minat melanjutkan studi ini disebabkan oleh dua faktor, yaitu faktor yang disebabkan dari dalam diri siswa itu sendiri dan faktor yang disebabkan dari luar. Faktor dari dalam yaitu kurangnya rasa senang siswa untuk melanjutkan studi, kurangnya ketertarikan siswa untuk melanjutkan studi, sedikitnya perhatian siswa dalam melanjutkan studi, keterlibatan siswa yang kurang dalam pembelajaran, kurangnya keyakinan siswa terhadap kemampuannya sendiri, dia tidak yakin apakah dia bisa atau tidak dalam melanjutkan studinya, kurangya motivasi dari dalam diri siswa dan faktor dari luar yaitu tidak adanya dukungan dari keluarga, ekonomi atau keadaan keluarga yang tidak memadai, serta bergaul atau berteman dengan teman-teman yang sudah tidak sekolah yang memilih untuk kerja dari pada melanjutkan studi kepergurua tinggi.

Setelah guru BK mengetahui permasalahan yang dialami oleh pesertadidiknya guru BK mengambil tindakan dalam membantu peserta didiknya yaitu dengan memberikan layanan bimbngan Konseling karir yang dilaksanakan secara bimbingan kelompok secara efektif dengan waktu yang cukup memadai agar dapat mengatasi masalah yang dihadapi siswa yaitu rendahnya minat melanjut kanstudi. Sebelum melaksanakan proses pemberian layanan bimbingan konseling karir yang di laksanakan secara bimbingan kelompok guru BK mendata atau mengidentifikasi masalah yang dialami siswa atau peserta didik.setelah guru BK mendapatkan pesertadidik yang harus di tangani maka guru BK memanggil peserta didik yang bermasalah tersebut dan bersepakatu ntuk melakukan layanan bimbingan konseling karir yang di laksanakan secara bimbingan kelompok sesuai dengan waktudan jam yang telah disepakati.

Setelah selesai melakukan pelaksanaan layanan bimbingan konseling karir yang dilaksanakan secara bimbingan klompok ternyata hasil yang didapatkan cukup baik walaupun belum maksimal,karena dilihat dari pengamatan yang ada bahwa siswa atau peserta didik yang tahap demi tahap terlihat termotivasi dan bersemangat dalam mencari informasi tentang perguruan tinggi, lebih semangat dan giat dalam belajar agar bisa masuk keperguruan tinggi yang mereka inginkan dan mereka terlihat lebih yakin dengan kemampuan yang merekamiliki.

Setelah peneliti mengamati upaya guru BK dalam menerapkan layanan bimbingan konseling karir yang di laksanakan secara bimbingan kelompok untuk meningkatkan rendah nya minat siswa melanjutkan studi kepada pesertadidik, peneliti dapat menyimpulkan bahwa guru BK yang melakukan belum maksimal, tetapi meski belum maksimal guru BK sangat antusias melakukan nya karena ingin peserta didik nya memiliki keinginan atau minat yang tinggi untuk melanjut kan studi kejenjang yang lebihtinggi.

Data yang di peroleh tersebut membuktikan bahwa pelaksanaan layanan bimbingan konseling karir dapat meningkatkan minat siswa melanjut kan studi siswa kelas XII SMA YADIKA Natar Lampung Selatan, walau pun belum semua tetapi pelaksanaann yang diberikan guru BK sudah dilakukan secara maksimal.

Berdasarkan penemuan peneliti pelaksanaan layanan bimbingan konseling karir dalam meningkatkan minat siswa melanjutkan studi di SMA YADIKA Natar Lampung Selatan, peneliti menemukan upaya guru BK melakukan dengan yang pertama melaksanakan identifikasi kepada pesertadidik, memberikan treatmen layanan bimbingan konseling karir yang di laksanakan secara bimbingan kelmpok.

\section{Simpulan dan Saran}

Berdasarkan hasil penelitian dan analisis hasil pada bab sebelumnya, maka pada bab ini penulis dapatsimpulkansebagai berikut: Pelaksanaan layanan bimbingan konseling karir dalam meningkatkan minat siswa melanjutkan studi siswa kelas XII SMA YADIKA Natar Lampung Selatan berdasarkan latar belakang masalah timbul karenayaitu kurangnya rasa 
senang siswa untuk melanjutkan studi, kurangnya ketertarikan siswa untuk melanjutkan studi, sedikitnya perhatian siswa dalam melanjutkan studi, keterlibatan siswa yang kurang dalam pembelajaran dan ada juga yang dikarenalan faktor ekonomi keluarga yang kurang memadai. Berdasarkan hasil observasi, wawancara dan dokumentasi, pelaksanaan layanan bimbingan konseling karir dalam meningkatkan minat siswa melanjutkan studi siswa kelas XII SMA YADIKA Natar Lampung Selatan yaitu dilak sanakan dengan cara yang pertama melakukan identifika sisiswa, hal ini dilakukan untuk mengetahui data tentang siswa dan yang kedua pelaksanaan layanan bimbingan konseling karir dilasanakan secara bimbingan kelomokhal ini dilakukan karena siswa memiliki masalah yang sama yaitu masalah dalam rendahnya minat siswa melanjutkan studi dan layanan ini dilakukan dengan tujuan untuk meningkatkan minat siswa dalam melanjutkan studi. Setelahlayanan selesai guru BK tetap melakukan pengamatan.

Sebagai guru bimbingan konseling harus lebih focus kepada peserta didik dan berikan layanan bimbingan konseling secara maksimal. Untuk peserta didik atau siswa pendidikan sangatlah pentinguntuk masa depan, jangan pernah bosan untuk menuntut ilmu. Jaga selalu semangat belajar, junjunglah ilmu setinggi mungkin. Karena dengan ilmu kita bias merubah segalanyaa.

\section{Daftar Pustaka}

ABKIN. 2007. Rambu-Rambu Penyelenggaraan Bimbingan dan Konseling Dalam Jalur Pendidikan Formal: Standar Kompetensi Kemandirian Peserta Didik. Jakarta: Direktorat Jenderal Peningkatan Mutu Pendidikan dan Tenaga Kependidikan Departemen Pendidikan Nasional.

Anoraga, Pandji. 2001. Psikologi Pendidikan. Jakarta: Rineka Cipta.

Arikunto, Suharsimi. 2002. Prosedur Penelitian Suatu Pendekatan Praktik. Jakarta: Rineka Cipta.

Asrori. 2011. Hubungan Minat Melanjutkan Studi Ke Perguruan Tinggi Dan Motivasi Belajar Dengan Prestasi Belajar. Skripsi tidak diterbitkan. UMM.

Azwar, Saifuddin. 2004. Metode Penelitian. Yogyakarta: Pustaka Pelajar.

Dalyono, M. 1997. Psikologi Pendidikan. Jakarta: Rineka Cipta.

Dastramita, Abas dkk. 1994. Bimbingan Karir. Jakarta: Depdikbud.

Djamarah, Syaiful Bahri. 2002. Psikologi Belajar. Jakarta: Rineka Cipta.

Gani, R.A. 1996. Bimbingan Karir. Bandung: Angkasa.

Japar, M. 1998. Pemahaman Individu I. Magelang: FKIP Universitas Muhammadiyah Magelang.

Junardi, dkk. 1990. Bimbingan Konseling Sekolah. Semarang: IKIP Semarang Press.

Hendrarno, dkk. 2003. Bimbingan dan Konseling. Jakarta: Dunia Pustaka Jaya.

Hurlock, E.1980. Psikologi Perkembangan: Suatu Pendekatan Sepanjang Rentang Kehidupan. Jakarta: Erlangga.

---------. 2004. Kamus Lengkap Psikologi. Jakarta: Grafindo.

http://konselingpendidikan.blogspot.com/17/03/2012/efektifitas-bimbinganpribadi.htmlefektifitas. [di akses tanggal 3 Juli 2013].

Munandir. 1996. Program Bimbingan Karier di Sekolah. Jakarta: Depdikbud.

Nasir, Mohammad. 1997. Metode Penelitian. Bandung: Ghalia Indonesia. 
Nurihsan, A.H. 2005. Strategi Layanan Bimbingan dan Konseling. Bandung: Refika Aditama.

Nasution, S. 2003. Metode Research (Penelitian Ilmiah). Jakarta: Bumi Aksara.

Nazir, Moh. 2005. Metode Penelitian. Bogor: Ghalia Indonesia.

Prayitno \& Erman Amti. 1999. Dasar-dasar Bimbingan dan Konseling. Jakarta: Rineka Cipta.

Rosyadah rani, 2010, Meningkatkan Minat Karier Melalui Layanan Bimbingan Konseling Kelompok. Skripsi Tidak diterbitkan. UNSRI

Ruslan, A. Gani. 1993. Bimbingan Karier. Bandung Angkasa.

Savina, Sinta Ekawati. 2012. Pengaruh Terapi Kontrol Diri Terhadap Self- Regulation Anak Putus Sekolah. Skripsi tidak diterbitkan. UMM.

Slameto. 1991. Perspektif Bimbingan Konseling dan Penerapannya diberbagai Institusi. Semarang: Satya Wacana.

Sukardi. 2008. Metode Penelitian Pendidikan. Jakarta: Bumi Aksara.

Susanti, Nuri. 2012. Upaya Meningkat Minat Membaca pada Buku Pelajaran Melalui Bimbingan Konseling Pribadi pada Siswa Kelas VIII D SMP N 7 Semarang. Kumpulan Skipris. UNSRI

Syach, Muhibbin. 2000. Psikologi Pendidikan dan Pendekatan Baru. Bandung: PT. Remaja Rosdakarya. 2003. Psikologi Belajar. Jakarta: Raja Grafindo Persada.

Undang-Undang Republik Indonesia Nomor 20 Tahun 2003 Tentang Sistem Pendidikan Nasional.

Winkel, W.S. 1997. Bimbingan dan Konseling di Institusi Pendidikan. Jakarta: PT Grasindo.

Yusuf, S. dan J. Nurihsan. 2005. Landasan Bimbingan dan Konseling. Bandung: PT. Remaja Rosda Karya.

2012. Efektifitas Bimbingan Pribadi. 